międzywojennej. Autorka dokonała próby analizy ilościowej i jakościowej żydowskich podręczników szkolnych. Problematyce mniejszości żydowskiej było poświęcone również wystąpienie dr Haliny Raczek z UMCS w Lublinie, która zaprezentowała działalność oświatową społeczności żydowskiej na lubelszczyźnie w okresie międzywojennym.

Kolejna referentka mgr Małgorzata Balukiewicz z Uniwersytetu Śląskiego w Katowicach omówiła „Działalność towarzystwa dla opieki nad żydowskimi sierotami we Lwowie (1916 - 1939)”. Następnie dr Ewa Witkowska z Uniwersytetu Lódzkiego w komunikacie z badań przedstawiła szkolnictwo mniejszości narodowych w Lodzi w XIX i XX wieku. Wobec dostępności źródel referentka postulowała potrzebę dalszych badań i opracowań. Wystapienie mgr Elżbiety Magiery z Uniwersytetu Szczecińskiego wskazywało na problem mniejszości narodowych w jędrzejewiczowskiej reformie programu historii dla szkół powszechnych w okresie międzywojennym. Natomiast referat dr Władysławy Szulakiewicz z WSP w Rzeszowie poświęcony był Wandzie Bobrowskiej-Nowak jako dydaktykowi historii wychowania.

Odmiennej problematyki dotyczyło wystąpienie dr Ryszardy Cieżniewskiej z WSP w Bydgoszczy, ukazujące niemiecka mniejszość narodowa w bydgoskich szkołach w latach 1920-1939. Przedstawiciel Uniwersytetu w Rydze Eryk Jekabson scharakteryzował oświatę na Lotwie w latach 1914-1940. Prof. dr hab. Eleonora Sapia-Drewniak wespół z dr Leonardem Smołka z WSP w Opolu przedstawili szkolnictwo polskie na Sląsku Opolskim. Ostatnie wystąpienie dr Stefanii Walasek z Uniwersytetu Wrocławskiego było poświęcone młodzieżowym organizacjom polskim na Lotwie w latach $1934-1940$.

W dyskusjach poruszano problemy związane z brakiem dostępu do źródeł znajdujących się poza granicami Polski oraz obiektywnością interpretacji badan. Wyjaśniono kwestie terminologiczne dotyczące nazewnictwa języków mniejszości żydowskiej. Poruszono sprawę mniejszości białoruskiej oraz czynników warunkujących jej rozwój, a także dyskutowano na temat mniejszości rosyjskiej i polityki kościoła prawosławnego wobec szkolnictwa.

Sformułowano następujące postulaty badawcze: 1) istnieje potrzeba badań podręczników mniejszości narodowych, w szczególności podręczników żydowskich; 2) wyrażono potrzebę badań roli mniejszości narodowych w kulturze i oświacie polskiej przez historyków wychowania reprezentujących określone mniejszości; 3) wskazywano na potrzebę badań sprawozdań z posiedzeń senatu w II Rzeczypospolitej w kontekście mnijeszości narodowych; 4) podkreślano konieczność podjęcia badań związanych z działalnością i poglądami historyków wychowania w Drugiej Rzeczypospolitej.

Organizatorzy zapowiedzieli druk referatów.

Elżbieta Magiera

\title{
XII Zjazd Szkoleniowo-Naukowy Logopedów
}

W dniach 11 - 13 października 1996 r. w Lublinie odbył się XII Zjazd Szkoleniowo-Naukowy Logopedów połączony z Walnym Zebraniem Członków Polskiego Towarzystwa Logopedycznego. Miejscem obrad była Aula Instytutu Fizyki UMCS. W Zjeździe wzięło udział prawie 200 osób. Z Irlandii przyjechała dr Patricia Dowd, wiceprzewodnicząca Komitetu Stałej Lączności Ortofonistów i Logopedów w Unii Europejskiej. W związku z 33 rocznicą założenia, a 30 - rejestracji Polskiego Towarzystwa Logopedycznego tematem Zjazdu byli: LUDZIE, WYDARZENIA I OSRODKI POLSKIEJ LOGOPEDII. Tematyka referatów i dyskusji dotyczyła oczywiście nie tylko ostatnich trzydziestu lat. Przewodniczący PTL prof. B. Adamczyk podkreślił, iż ,(...) musimy również pamiętać o ludziach, wydarzeniach i ośrodkach sprzed wielu, wielu lat, dających początki, 
a nawet podstawy polskiej logopedii. Nie zapominajmy więc o tym, co było, by w przyszłości nie zapomniano o nas!". Wątek historyczny przewijał się przez większość wystąpień. Narastanie refleksji logopedycznej było m.in. tematem referatu S. Grabiasa z Zakładu Logopedii i Językoznawstwa Stosowanego UMCS. M. Jędrzejczak przedstawił fakty i źródła zwiazane z funkcjonowaniem pierwszych w Polsce poradni rehabilitacyjnych dla dzieci głuchych. Omówiono m.in. historię logopedii na Śląsku (M. Chęciek, I. Nowakowska-Kempna), poznańska myśl logopedyczną (K. Błachnio), opiekę logopedyczna (począwszy od dwudziestolecia międzywojennego) w Klinice Foniatrii i Audiologii AM w Poznaniu (A. Obrębowski), terminologię związana $z$ wadami wymowy na przestrzeni dziejów (A. Sołtys-Chmielowicz), międzywojenna nomenklaturę logopedyczną (E. Kuczyńska). Należy podkreślić, że 21 spośród 23 wygłaszanych na Zjeździe referatów wydrukowano w Logopedii 23 , którą wszyscy uczestnicy otrzymali przed rozpoczęciem obrad.

Wiele mówiono w Lublinie o zasługach „ojca polskiej logopedii" prof. L. Kaczmarka. Wyrażano żal z powodu Jego nieobecności na lubelskim Zjeździe i w związku z tym zredagowano list, w którym m.in. podkreślono olbrzymią rolę, jaką odegrał w rozwoju powojennej logopedii ${ }^{1}$. Niewątpliwym urozmaiceniem pierwszego dnia obrad byl, jak to zapowiedziano w programie, „pokaz popularno-naukowo-rozrywkowy", w którym przewodniczący PTL pokazał „drugą twarz", tzn. prezentując kilka prostych doświadczeń przypomniał uczestnikom Zjazdu, że z wykształcenia jest fizykiem.

W ostatnim dniu Zjazdu odbyło się Walne Zebranie Członków PTL, podczas którego wybrano nowy Zarząd Glówny. Przewodniczyć będzie mu nadal prof. B. Adamczyk.

Ewa Kuczyńska

\section{Konferencja naukowa: Historyk nauk medycznych wobec inspiracji badawczych. Teoria i tradycja}

W dniach 18 -19 października 1996 r. odbyła się w Poznaniu konferencja naukowa pt: „Historyk nauk medycznych wobec inspiracji badawczych. Teoria i tradycja”. Została zorganizowana pod protektoratem Instytutu Historii Nauki Polskiej Akademii Nauk i Fundacji Humanitas Et Scientia. Inicjatorem konferencji byl dr Jaromir Jeszke z Zakładu Historii Nauk Medycznych Akademii Medycznej im. Karola Marcinkowskiego w Poznaniu. Obrady odbywały się w Ośrodku Nauki PAN w Poznaniu przy ulicy Wieniawskiego 17. W konferencji uczestniczyli naukowcy zajmujący się problematyką historii medycyny z kraju, z Niemiec oraz przedstawiciele studentów.

W pierwszym dniu konferencji wygłoszono następujące referaty:

Jaromir Jeszke - Lekarz i historyk jako badacze dziejów nauk medycznych; Tadeusz Brzeziński - Historia nauk medycznych jako dyscyplina medyczna; Wojciech Wrzosek - Historia nauk medycznych jako dyscyplina historyczna; Bożena Płonka-Syroka - Niemiecka medycyna romantyczna w historiografii XIX i XX stulecia; Adam Paluch - Uwagi etnologa wobec historii medycyny;

${ }^{1}$ Profesor Leon Kaczmarek zmarł 26 października 1996 r, dwa tygodnie po Zjeździe Polskiego Towarzystwa Logopedycznego, którego dzialalność inicjował w 1963 r. 